\title{
A Critical Analysis of a Chapter from an EFL Textbook: a TBLT Perspective
}

\author{
Andri Suherman \\ Language Centre, University of Mataram, Indonesia \\ Correspondence: Andri Suherman, University of Mataram, Indonesia. E-mail: andrisuherman123@gmail.com \\ Received: Juli 17, 2018 \\ Accepted: September 01, 2018 \\ Online Published: September 15, 2018 \\ doi: 10.29408/veles.v2i2.801.g601 \\ URL: http://dx.doi.org/10.29408/veles.v2i2.801.g601
}

\begin{abstract}
This research article aimed to analyze tasks employed in an Indonesian EFL textbook from the perspective of TBLT approach. The analysis involved chapter eight in the EFL textbook of grade ten. Meanwhile, the six features of a task proposed by Ellis (2003) were used to analyze the tasks. The findings revealed two points; (1) none of the fifteen tasks in the chapter employed the six crucial features of a task, (2) all the fifteen tasks in the chapter were potential to change to be more task-like. The implication of this study was to provide insight to EFL material developers to be more aware of the task features, and to offer suggestions to EFL education practitionersin redesigning existed tasks to be more task-like.
\end{abstract}

Keywords: EFL textbook, task features, TBLT approach.

\section{Introduction}

Over the last few decades, CLT (Communicative Language Teaching) has been the most popular language teaching method. Communicative competence, introduced in the early 1970s by Savignon (1972), is the key theoretical point of CLT approach. As time went by, the language teaching methods had encountered many changes. The term of TBLT (Task-Based Language Teaching) gradually emerged which was promoted by Prabhu (1987). He argued that learners can obtain effective knowledge when the learning outcome is focused on the task, not in the language being used by learners. He further established three stages of tasks in the language learning: pretask, task cycle, and post-task.

Similarly, Brown (1994) claimed that the main purpose of TBLT is in the language use, not in the language form. Furthermore, Long \& Robinson (1998) argued that TBLT draws learners' attention to some aspects of language code by developing pedagogical tasks. As such, pedagogy includes a series of tasks, not only one task. However, Larsen-Freeman (2000) argued that TBLT focuses on meaningful communication without under developing language form. On 
the other hand, Leaver \& Willis (2004) claimed TBLT as a branch of CLT. In other words, the focus of TBLT is on the connection of language learning to the real-world context.

Nevertheless, Willis (1996) argued that TBLT is a reaction to the criticism of several traditional approaches such as TPR (Total Physical Response), Audio Lingual Method, or PPP (Presentation, Practice, and Production). As he claimed, these traditional approaches emphasize the accuracy by specifying the target language in advance. As a result, the language production is stilted. To distinguish TBLT from traditional methods, Rozati (2014) highlighted several points. First, while the focus of traditional methods is deliberate, focus on form is unintentional in TBLT. Second, in traditional methods, communicative skill is not mainly considered. However, communicative skill is centered in TBLT. Third, new language is intentionally delivered in traditional methods. Contrary, new language is confronted unintentional during tasks in TBLT. Fourth, traditional methods have noticeable focus on specific forms, but TBLT has no focus on specific form. Fifth, learning process is mainly teacher-led in traditional methods, but learning process is learners-centered in TBLT.

Rozati (2014) further stated that TBLT treats language use in the centre of both syllabus and methodology. Nevertheless, the notion of a task embedded in TBLT drew attention from many linguists.

Linguists describe the notion of a task differently. For example, Richard, Plat \& Weber (1986) argued that task is a classroom activity carried out as a production of processing the language. They claim that a task involves communicative skill to engage to learners focus on meaning, rather than on linguistic features. Meanwhile, Willis (1996) defined a task as a language activity which motivates learners to communicate by using target language to achieve the outcome. Similarly, Bygate (2001) claimed a task as a language activity which requires learners to use the language, to comprehend the meaning, and to achieve the goal. In contrast, Nunan (1999) distinguished a task from an exercise. He stated that a task has a non-linguistic outcome, but an exercise has a linguistic outcome.

Instead of exploring the definition of a task, Ellis (2003) mentioned the criteria a task should have. The following is six task features he proposed are: First, a task provides a work plan. Second, a task focuses on meaning. Third, a task reflects real-world processes. Fourth, a task involves any four language skills (listening, speaking, writing, reading). Fifth, a task engages cognitive processes. Sixth, a task has clear communicative outcomes. These six features were used to analyze the data sample in this study. Explanation of each feature was then explored in the discussion session. Thus, this study ought to answer the following two research questions: (1) Do the tasks in the chapter employ the six criteria features of a task?, (2) What tasks can be redesigned to make them more task-like?

\section{Method}

\subsection{Data Samples}

The chapter analyzed in this study was chapter eight titled "My Idol" on page 108 from an Indonesian EFL textbook "Bahasa Inggris Kelas X" by Furaidah, et al (2016). This textbook is 
currently being used by grade ten of Senior High School students, and has been revised with curriculum 13, compiled by the Ministry of Education and Culture, Indonesia.

\subsection{Data Collection}

\subsubsection{Instrument of Collecting Data}

The textbook analyzed in this study consisted of 15 chapters. As stated in the preface of the textbook, all the chapters in implement PPP (Presentation, Practice, and Production) approach. Among these chapters, chapter eight was choose to be analyzed because this chapter seemed to potentially be redesigned to be more task-like.

\subsubsection{Techniques for Collecting Data}

The chapter was firstly analyzed whether it employed the six crucial features of a task by Ellis (2003). Each skill and comprehension was analyzed within each session. After that, a revision was proposed to make it more task-like.

\subsection{Data Analysis}

The six features of a task proposed by Ellis (2003) were used to analyze each task in the chapter. The sample of revision was then suggested to make the task in the chapter to be more task-like.

\section{Results}

\subsection{Do the tasks in the chapter employ the six criteria features of a task?}

The following table shows the result of identifying the task features in each task employed in chapter eight. The task features used in this study were those proposed by Ellis (2003).

\begin{tabular}{|c|c|c|c|c|c|c|}
\hline \multirow[b]{2}{*}{ Tasks } & \multicolumn{6}{|c|}{ Task Features } \\
\hline & $\begin{array}{l}\text { provide a } \\
\text { work plan }\end{array}$ & $\begin{array}{l}\text { focus on } \\
\text { meaning }\end{array}$ & $\begin{array}{l}\text { reflect real } \\
\text { world } \\
\text { language use } \\
\end{array}$ & $\begin{array}{l}\text { involve } 4 \\
\text { language } \\
\text { skills }\end{array}$ & $\begin{array}{l}\text { engage } \\
\text { cognitive } \\
\text { processes }\end{array}$ & $\begin{array}{l}\text { has a clear } \\
\text { communicative } \\
\text { outcome }\end{array}$ \\
\hline warmer (p.109) & no & yes & yes & $\mathrm{S}, \mathrm{L}$ & LOTS & no \\
\hline $\begin{array}{l}\text { vocabulary builder } \\
\text { (p.109) }\end{array}$ & no & no & no & $\mathrm{R}, \mathrm{S}$ & LOTS & no \\
\hline $\begin{array}{l}\text { Pronunciation practice } \\
\text { (p.110) }\end{array}$ & no & no & no & $\mathrm{L}, \mathrm{S}$ & LOTS & no \\
\hline Reading (p.110-111) & no & no & no & $\mathrm{R}$ & LOTS & no \\
\hline $\begin{array}{l}\text { Vocabulary exercises: Task } \\
1(\text { p.112) }\end{array}$ & no & no & no & $\mathrm{R}, \mathrm{S}, \mathrm{L}$ & LOTS & no \\
\hline $\begin{array}{l}\text { Vocabulary exercises: Task } \\
2 \text { (p.113) }\end{array}$ & no & no & no & $\mathrm{R}$ & LOTS & no \\
\hline $\begin{array}{l}\text { Text Structure: } \\
\text { Task } 1 \text { (p.114) }\end{array}$ & no & no & no & $\mathrm{R}$ & LOTS & no \\
\hline Text Structure: & no & no & $\begin{array}{l}\text { no } \\
68\end{array}$ & $\mathrm{R}, \mathrm{W}$ & LOTS & no \\
\hline
\end{tabular}


Task 2 (p.114)

$\begin{array}{lcccccr}\begin{array}{l}\text { Text Structure: } \\ \text { Task 3 (p.115) }\end{array} & \text { no } & \text { yes } & \text { yes } & \text { S,L } & \text { HOTS } & \text { no } \\ \begin{array}{l}\text { Grammar review: } \\ \text { Task 1 (p.115) }\end{array} & \text { no } & \text { no } & \text { no } & \text { R } & \text { LOTS } & \text { no } \\ \begin{array}{l}\text { Grammar review: } \\ \text { Task 2 (p.115) }\end{array} & \text { no } & \text { yes } & \text { no } & \text { R,S } & \text { LOTS } & \text { no } \\ \text { Speaking: Task 1 (p.116) } & \text { no } & \text { yes } & \text { yes } & \text { S } & \text { HOTS } & \text { no } \\ \text { Speaking: Task 2 (p.116) } & \text { no } & \text { no } & \text { yes } & \text { W,S,L } & \text { HOTS } & \text { no } \\ \text { Speaking: Task 3 (p.116) } & \text { no } & \text { yes } & \text { yes } & \text { W,S } & \text { HOTS } & \text { no } \\ \text { Writing (p.118) } & \text { no } & \text { no } & \text { no } & \text { W } & \text { LOTS } & \text { no }\end{array}$

Note: $\mathrm{S}=$ speaking; $\mathrm{L}=$ listening; $\mathrm{R}=$ reading; $\mathrm{W}=$ writing; HOTS= High Order Thinking Skill; LOTS= Lower Order Thinking Skill

As indicated by the table above, all of the tasks in the chapter do not provide a work plan. Similarly, none of the tasks have a clear communicative outcome. On the other hand, among these 15 tasks, only 5 tasks focus on meaning and reflect real world language use. Meanwhile, the fourth feature displays different trend. Reading skill and speaking skill are employed in many tasks. In contrast, only in very few tasks are listening skill and writing skill employed. In terms of the fifth feature (engage cognitive processes), most of the tasks employ Lower Order Thinking Skills (LOTS). Only 4 tasks in the chapter employ High Order Thinking Skills (HOTS).

\subsection{What tasks can be redesigned to make them more task-like?}

All the fifteen tasks in the chapter can potentially be revised to make them more task-like. Take warmer session on page 109 as an example. This task has already employed four features of a task set out by Ellis (2003). It only misses the first and the last feature. To make it more tasklike, it can be revised by providing work plan like a series of stages on how to perform the task, not only a brief and unclear instruction. In addition, to make it task-based lesson, the task needs to state a clear communicative outcome, not only directs students to discuss the topic.

Several points are required to highlight when modifying a task. Willis \& Willis $(2007$, p.201) mentioned three important ways in revising a task. First, identify activities that only need "tweaking". Appraise any potential tasks in the light of learners' needs. As such, whether modify tasks in order to increase opportunities for planned speaking, repeated reading, or spontaneous writing. Then develop tasks into more effective tasks by implementing the relevant parameters such as adding a post-task stage, or adding a goal. Second, re-order activities. By this means, do the grammar session last, and do the skills lessons first. Third, add and integrate focused tasks. In this case, focused tasks are tasks which enable specific linguistic features are likely to occur naturally in learners' interaction. 


\section{Discussion}

Although all the fifteen tasks in the chapter employed several features of a task, most of them failed to include the combination of six features of a task proposed by Ellis (2003).

First, as stated before, none of the tasks in the chapter provide work plan. Breen (1989) distinguished between the task-as-work plan and task-as-process. He argued that the actual activity that results may not be like what the teachers might intend when planning a task-based learning. In other words, the task-as-work plan provides learners with freedom to autonomously use the languages to transact a task. Take task 1 of grammar review on page 115 as an example. It only provides brief instruction without mentioning of how the process should unfold. To conclude, a work plan is simply "a plan for learner activity" (Ellis, 2003). As such, a work plan can be some activities which form a task sequence, or can be a series of stages in one activity.

Second, rather than displaying language, a task should be designed to engage learners in using language pragmatically. A task involved communication skill to develop second language proficiency (Ellis, 2003). Therefore, it required a primary focus on meaning. In this case, a task incorporates some kind of gap which will encourage learners to use language to fill in the information gap. Instead of specifying what language should be used, the work plan allowed learners to choose and use the language they need to achieve the outcome of the task. Only few tasks in the chapter implemented this second feature.

Third, the work plan may require learners to engage in a language activity like what occur in the real world. In other word, it engages learners in an authentic communicative context. Alternatively, the work plan may involve learners in a language activity that is artificial (Ellis, 2003). However, the language activity that results from performing a task will reflect real-world communication. Several tasks in the chapter employ this third feature. Nevertheless, most of the tasks do not simulate genuine communicative activities.

Fourth, the percentage of each language skills involved in the tasks can be seen by this following bar chart:

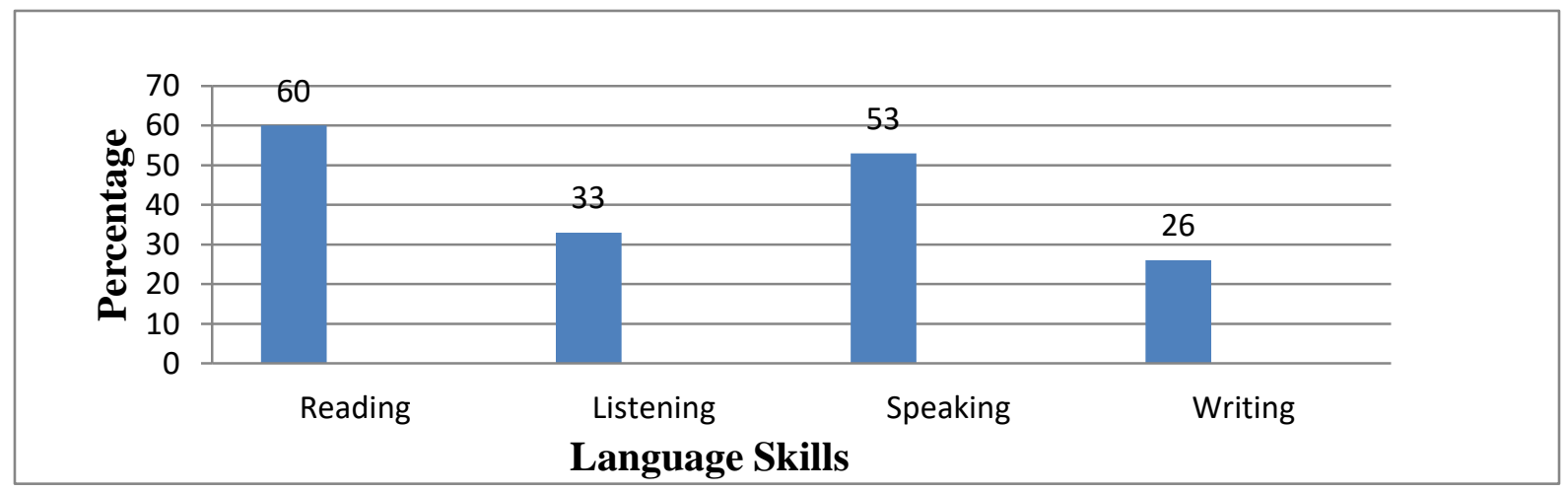


As displayed by the chart above, it is clear that the reading skill has the highest proportion $(60 \%)$ among other skills involved in the tasks, followed by speaking skill and listening skill with $53 \%$ and $33 \%$ respectively. Writing skill, on the other hand, account for only $26 \%$ of all tasks.

With the highest percentage, reading skill is employed in many tasks of the chapter. The most noticeable one is in reading session (p.110-111) where students need to read a text and answer the comprehension questions. Meanwhile, speaking skill is employed in some of the tasks. For example, in task 1 of speaking session (p.116) students need to retell their experiences of meeting Afgan (an Indonesian singer) by using their own words. Listening skill, on the other hand, is employed in a very few tasks. For example, in pronunciation session (p. 110) students listen to the teacher and repeat after him. Lastly, writing skill is the least frequent language skill employed in the chapter. For example, in writing session (p. 118) students write their holiday experience by following the step provided.

Fifth, the tasks in the chapter employed cognitive processes, both LOTS (Lower Order Thinking Skills) and HOTS (High Order Thinking Skills). These processes might influence learners to use a specific linguistic feature, but do not determine the language choice. In other words, these processes circumscribe the range of linguistic features learners will need to perform the tasks, but allow the actual choice of forms to remain with the learners. Several skills of cognitive processes have been employed in the chapter. In this case, Bloom's taxonomy was used to identify the range of cognitive processes the tasks might trigger.

This taxonomy claimed that the first three skills (remember, understand, apply) belong to LOTS, and the other three (analyze, evaluate, create) belong to HOTS. Both LOTS and HOTS were employed in the chapter. For example, warmer session on page 109 employed LOTS where students are required to recognize the famous artists shown and to recall or remember what they are famous for. Meanwhile, task 3 on page 115 employed HOTS where students are required to check or evaluate their answer with a partner and share it to the class.

Sixth, similar with the first feature, none of the tasks in the chapter has a clear communicative outcome. (Ellis, 2003) argued that the work plans should stipulate the nonlinguistic outcome as the goal of the task. In other words, the stated communicative outcome is an indicator which determines when learners have completed a task.

Basically, all the tasks in chapter eight can be redesigned to make them more task-like. Take the reading session on page 110 as an example. Since the text in this reading session is mainly recount, it is appropriate to implement a prediction task. For prediction task, Willis \& Willis (2007, p.34) recommend a task sequence which consists of seven stages.

First step is priming for prediction. This first step allows learners to get ready for the topic being raised. In this case, the teacher can say:

"Few days ago, I met my idol, Afgan. Can you predict what happened when I met him? Work in groups. Think as many predictions as you can." 
Students work in groups for some minutes to discuss their guess. After that, students are invited to tell their predictions with the class. This is a valuable activity in stretching learners' language resources to meet a communicative need.

Second one is prediction task. Teacher provides learners some lexical resources (words and phrases) taken from the text to equip learners with some key words they may need in the next tasks. For example:

$$
\begin{aligned}
& \text { met - concert - packed - singing performance - shouted - radio } \\
& \text { station - screamed - sang along - awesome - prepared - nervous } \\
& \text { - amazing person }
\end{aligned}
$$

Students keep working in groups to decide what exactly happened. They need to include all the words or phrases provided.

Third step is preparing for report. Teacher asks all groups to prepare one member to tell the story they have made. In this case, learners have a chance to rehearse some of the languages they will use at the upcoming task. Foster and Skehan (1999) claims that it is important to provide learners with some opportunities to allow them focus on the language resource to perform a task. They argue that a group work is a valuable learning opportunity to prepare learners' language complexity, accuracy, and fluency (CAF).

Fourth one is report. The member from each group reports their story to the whole class. This reporting stage is a target task representing storytelling, an activity we do with language in the real world. While listening to the story, the other groups compare their stories.

Fifth step is reading. Students read the true story showed by the teacher. In this case, reading is another target task because students read the true story while checking if their initial predictions are accurate. This reading task can satisfy the students' curiosity about the story. In other words, learners will be reading primarily for meaning to check their guess and satisfy their curiosity.

Sixth step is focus on form. This stage employs a Focus on Form (FoF) activity. Skehan (2013) argues that teacher needed to clarify the insight or knowledge further that occurs from the previous tasks. In this case, teacher can ask learners to underline all the words in the text which indicate past verbs (went, heard, smiled, waved, etc).A teacher-led discussion is then required to introduce learners a grammatical feature, in this case simple past tense.

Last step is evaluation. It is worth checking learners' reaction or opinion regarding the prediction task. Teacher can ask learners whether the prediction task is too difficult or too easy to do, or whether they need more help with lexical priming, or whether they feel the language was useful. These kinds of questions help learners to discuss and evaluate with their group. Willis and Willis (2007, p.40) mentioned three functions of this evaluation stage:

1. It involves meaning-focused language use which can engage learners in genuine communication. It is also a good language practice because it has a real outcome. 
2. It will help teacher to adjust the task for future use. In other words, it helps teacher to decide whether the task is worth doing again.

3. It helps to raise learners' motivation because they have been involved in decision making and take notice of their reactions.

\section{Conclusion}

This study presented a critical analysis of tasks employed in chapter eight titled "My Idol" in an Indonesian EFL textbook from the perspective of TBLT approach. Six crucial features of a task proposed by Ellis (2003) were used to analyze each task in the chapter. Regarding research question 1, finding revealed that the tasks failed to employ the first feature (provide work plans) and the sixth feature (have communicative outcome). In other words, none of the tasks in the chapter employed these two features. Meanwhile, the second feature (focus on meaning) and the third feature (reflect real-world language use) were not employed adequately in the chapter. In terms of the fourth feature (involve any of four language skills), some of the tasks employed one skill, others employed two skills or three skills, but no tasks employed the combination of four skills. Similar trend was showed by the fifth feature (engage cognitive process). Some of the tasks employed High Order Thinking Skills (HOTS) such as analyzing, evaluating and creating. In contrast, some others employed Lower Order Thinking Skills (LOTS) such as remembering, understanding, and applying. Regarding research question 2, the finding revealed the possibility of redesigning the potential tasks in the chapter to make them more task-like. The modified version of reading session suggested in the discussion part above was one out of many ways to revise the task into task-based learning.

The results of this study could provide insight for material developers to become more aware of the six task features employed in EFL textbooks. Furthermore, this study may also provide another valuable insight for education practitioners in revising EFL materials to be more tasklike. Nevertheless, despite these insightful implications, several limitations should be noted. First, this study only analyzed one chapter in the textbook as the data sample. There are other eleven chapters remained and they probably have adopted task-based lesson. Second, this study only proposed one task in the chapter to revise using prediction task. There are other fourteen tasks remained which can potentially be modified into task-based learning using different methods such as discussion task, jigsaw task sequence, or general knowledge task.

\section{References}

Brown, H. D. (1994). Teaching by principles: An interactive approach to language pedagogy. NJ: Prentice-Hall.

Bygate, M. (2001). Effects of task repetition on the structure and control of oral language. In M. Bygate, P. Skehan, \& M. Swain (Eds.), Research pedagogic tasks: Second language learning, teaching, and testing (pp. 23-48). Harlow, UK: Longman. 
Breen, M. (1989). The evaluation cycle for language learning tasks. In R.K. Johnson (Eds.), The second language curriculum. Cambridge: Cambridge University Press.

Ellis, R. (2003). Task-based language learning and teaching. Oxford: Oxford University Press.

Foster, P. , \& Skehan, P. (1999). The influence of source of planning and focus of planning on task-based performance. Language Teaching Research, 3, 3: 215-247.

Furaida., Rohmah, Z., Widiati, U., (2016). Bahasa Inggris kelas X. Jakarta: Pusat Kurikulum dan Perbukuan, Baliktbang, Kemdikbkud.

Larsen-Freeman, D. (2000). Techniques and principle in language teaching, 2nd ed. Oxford: Oxford University Press.

Leaver, L., \& Willis, J. (2004). Task-based instruction in foreign language education: Practices and Programs. Washington, D.C.: Georgetown University Press.

Long, M. H., \& Robinson, P. (1998). Focus on form: Theory, research, and practice. In C.

Doughty \& J. Williams (Eds.), Focus on form in classroom second language acquisition (pp. 1541). Cambridge: Cambridge University Press.

Nunan, D. (1999). Second language teaching and learning. Boston: Heinle Thomson.

Prabhu, N. (1987). Second Language Pedagogy. Oxford: Oxford University Press.

Richards, J. C., Platt, J. \& Weber, H. (1986). Longman Dictionary of Applied Linguistics London. Harlow, U.K.: Longman Addison-Wesley.

Rozati, S., M. (2014). Language teahing and task base approach. Theory and Practice in Language Studies, 4 (6), 1273-1278. http://dx.doi.org/10.4304/tpls.4.6.1273-1278

Savignon, A. (1972). Communicative competence: An experiment in foreign language teaching. Centre for Curriculum Development: Philadelphia.

Skehan, P. (2013). Nurturing Noticing. In J. M. Bergsleither, S. N. Frota, \& J. K. Yoshioka (Eds.), Noticing and second language acquisition: Studies in honor of Richard Schmidt (pp. 169-182). Hawai'i: National Foreign Language Resource Centre.

Willis, D. ,\& Willis, J. (2007). Doing task-based teaching. Oxford: Oxford University Press. Willis, J. (1996). A Framework for Task-Based Learning. Harlow : Longman. 